\title{
Oocyte size and intrafollicular position in polyovular follicles in rabbits
}

\author{
W. Al-Mufti, O. Bomsel-Helmreich and J. Ph. Christidès† \\ Unité 187, INSERM, 32 rue des carnets, 92140 Clamart, and $† C . N . R . S$. Recherches sur la Nutrition, \\ 92190 Meudon, France
}

\begin{abstract}
Summary. Healthy follicles with 2-24 oocytes were observed in adult rabbit ovaries during all phases of folliculogenesis from primary to preovulatory follicles. Most follicles contained 2-3 oocytes which developed according to their topographical situation in the follicle. The central oocyte in a normal topographical situation has an almost normal growth and development up to metaphase II and cumulus expansion. The peripheral oocytes grow more slowly: most do not attain the normal size or resume meiosis and remain surrounded by ordinary granulosa cells. When the number of oocytes is higher than 3, the peripheral oocytes develop even more slowly, as do the central ones. It demonstrates the necessity for the oocyte to occupy a certain position inside the follicle and to reach a size which allows resumption of meiosis; the cumulus responds only to oocytes of normal size and position. We suggest that, despite the relative frequency of binovular follicles, fertilization of two oocytes originating from one follicle is unlikely.
\end{abstract}

Keywords: polyovular follicles; rabbit; oocyte size; oocyte position; fertilizability

\section{Introduction}

Polyovular follicles occur in the ovaries of many mammalian species, including women (see Hartman, 1926; Bacsich, 1949-1950; Dawson, 1951; Bodemer \& Warnick, 1961; Kent, 1962; Shehata, 1974; Papadaki, 1978). They are frequent in the opossum and the bitch (Hartman, 1926) and in bitches $17 \%$ of follicles seem to be polyovular. In all species so far studied, follicles with more than one ovum are mainly binovular: in women in which $0 \cdot 10-2 \cdot 40 \%$ of follicles are polyovular, $97 \%$ of polyovular follicles are binovular, $2.5 \%$ triovular and $0.4 \%$ have $>3$ ova (Gougeon, 1981).

Heredity seems to be one of the aetiological factors for polyovuly in hamsters (Plachot et al., 1977) and certain inbred strains of mice show a much higher proportion of ovaries with polyovular follicles (D. G. Whittingham, personal communication). However, their mode of origin and potential, as well as their developmental significance are still unknown. If they are able to ovulate such follicles could become a mechanism of dizygotic twinning in monovular species.

Hartman (1926) suggested that polyovular follicles were the result of accidental development, when groups of oocytes linked previously by intercellular bridges fail to be individually surrounded by follicle cells at the moment of follicle formation.

Most authors have primarily referred to preantral follicles but antral follicles are sometimes mentioned. Hartman (1926) reported that, in the opossum, oocytes in polyovular follicles had a complete zona pellucida, whatever their type.

Another proof of functional normality was the response of these follicles to exogenous gonadotrophins (Bodemer \& Warnick, 1961), when stimulated preantral polyovular follicles became antral but no further development was observed. Hartman (1926), Engle (1927) and Dawson (1951) are

*Reprint requests to Dr O. Bomsel-Helmreich. 
the only authors to mention differences in the size of the oocytes in the same follicle; they considered that only the large oocytes are able to survive. Ovulation from polyovular follicles was not ascertained but suggested by several authors, when the number of embryos exceeded the number of corpora lutea, and the possibility of one ovum dividing was excluded (Davis \& Hall, 1950). Zeilmaker et al. (1983) and Simonetti et al. (1985) described human follicles punctured for in-vitro fertilization as yielding 2 oocytes but ovulation was never demonstrated.

Polyovular follicles occur frequently in rabbits and we have studied these follicles during the whole course of folliculogenesis from the primary to the preovulatory stage and possible ovulation.

\section{Materials and Methods}

During various experiments on 102 rabbits, 7 ovaries containing polyovular follicles in remarkable numbers were selected for further examination: 5 ovaries belonged to 3 does that had received an ovulatory dose of hCG (50 i.u.) at the time of coitus and the other 2 belonged to a rabbit that had received no treatment. All animals were killed $8 \mathrm{~h}$ after coitus, $2 \mathrm{~h}$ before ovulation.

Ovaries were fixed in Bouin's solution and histological sections $(7 \mu \mathrm{m})$ were serially mounted and stained with Masson blue trichrome. All sections were observed.

Only developing follicles were considered, when oocytes were already surrounded by the zona pellucida. Primordial follicles were counted only when they were found inside a more developed polyovular follicle.

Follicles were classified according to Baker (1982) but with some modifications in labelling of oocytes in the polyovular follicles (Fig. 1). For normal follicles, the primary follicle contains an oocyte surrounded by one layer of granulosa (corresponds to a stage 2 follicle of Baker). The secondary follicle contains an oocyte surrounded by 2 layers of granulosa (stage 3). The tertiary follicle contains an oocyte surrounded by 3 or more layers of granulosa (stage 4-5). The antral follicle shows the appearance of a definite antrum (stage 6-7) and the preovulatory follicle has an oocyte which shows evidence of meiosis (stage 8).

The polyovular follicle was also defined by the number of granulosa layers surrounding the main oocyte. The primary follicle contains oocytes surrounded by one layer of granulosa cells, the oocytes are identified as larger (M) or smaller $(\mathrm{m})$. The secondary follicle contains a major (M) oocyte if surrounded by 2 layers of granulosa and a minor $(\mathrm{m})$ oocyte when surrounded by one layer. The tertiary follicle contains a major (M) oocyte, surrounded by 3 layers or more, intermediate (i) oocytes if surrounded by 2 layers and minor (m) oocytes surrounded by one layer. In the antral and preovulatory follicles, the oocytes are labelled central if nearest to the centre, mural if near the basement membrane and peripheral in between (Fig. 1). The average diameter of all developing oocytes was calculated by taking the mean of the two largest diameters inside the zona pellucida. All polyovular follicles with their oocytes of each ovary were recorded. In total, 255 polyovular follicles with 690 oocytes were observed (Table 1).
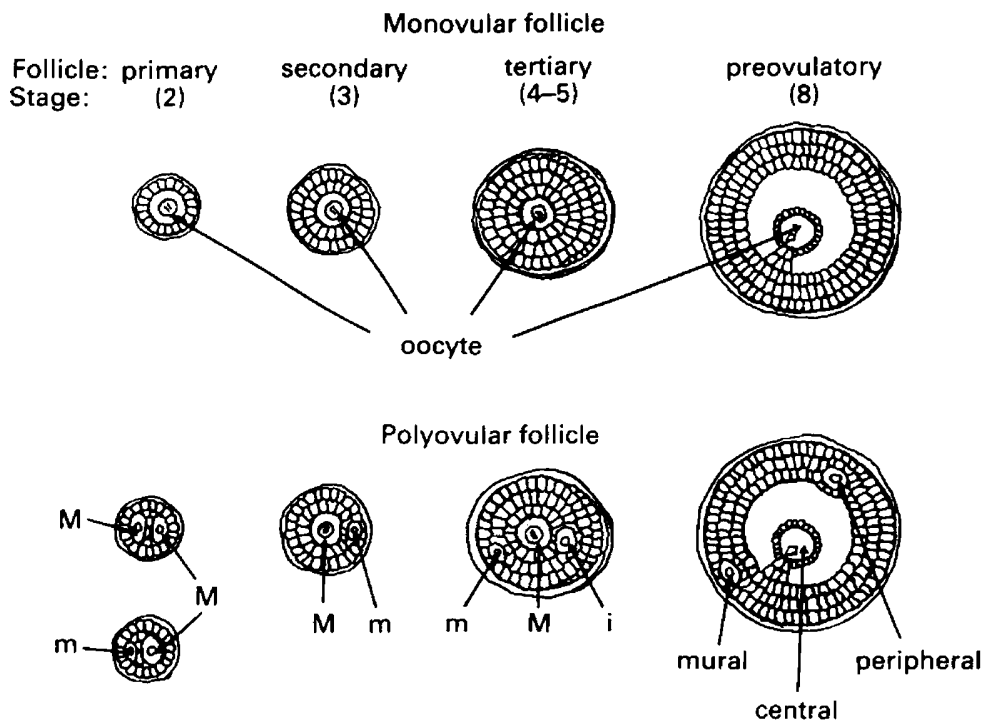

Fig. 1. Topographical localization and labelling of oocytes in monovular and polyovular follicles. Stages as defined by Baker (1982). $\mathrm{m}=$ minor oocyte; $\mathbf{M}=$ major oocyte; $\mathbf{i}=$ intermediate oocyte. 


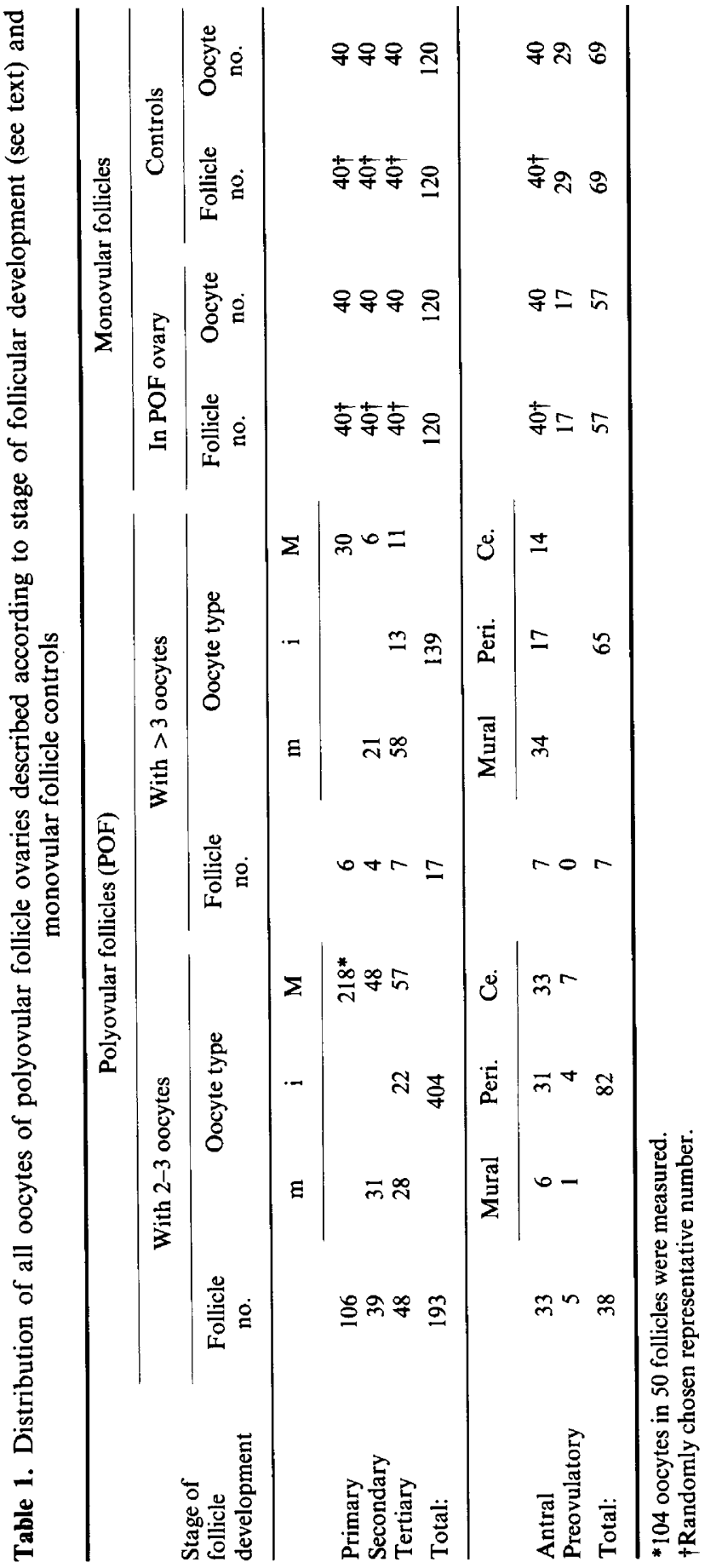


Two types of control follicles were used. First, 10 monovular follicles of the 5 above-mentioned follicle categories were measured in each of the 4 animals with polyovular follicles. However, only 177 instead of 200 follicles and oocytes could be examined because preovulatory follicles were not present in sufficient numbers. Secondly, normal control oocytes were measured in 4 ovaries belonging to 4 does containing only monovular follicles: 2 of these does had received hCG in comparable doses and timing as those with polyovular follicles. All were killed $8 \mathrm{~h}$ after coitus and 189 follicles and oocytes were examined.

Data are expressed as the mean \pm standard error of the mean (s.e.m.). The Wilcoxon test was used to determine the significance of the difference between means (Snedecor \& Cochran, 1957).

\section{Results}

Relation between oocyte growth and topographical position in polyovular follicles

In the 7 ovaries observed, 255 healthy follicles contained 2 or more oocytes. The follicles were in all stages of folliculogenesis, from primary to preovulatory.

In primary follicles the topographical situation of each oocyte was similar, all being surrounded by one layer of granulosa cells. In all the other follicles, one oocyte, sometimes two, occupied a rather central position. The supplementary oocytes were therefore abnormal in position, being more or less eccentric (Fig. 2).

Follicles with 2-3 oocytes. In the 7 ovaries there were 231 polyovular follicles with $2-3$ oocytes.

In 50 primary follicles, three types were seen, (1) both oocytes were small and equal in 22 follicles, (2) one was larger than the other in 22 follicles (Fig. 3), and (3) both oocytes were large in 6 follicles. Of the 218 oocytes observed, only 104 were measured because this sample was considered an adequate representation of all the oocytes of this stage.

In secondary follicles, the major oocyte was bigger than the minor oocyte, whereas in a tertiary follicle containing all three categories, the major oocyte was bigger than the intermediate oocyte which was bigger than the minor oocyte.

In antral follicles, topographical position inside the follicle correlated with the oocyte size, the central oocyte being larger than the peripheral which was larger than the mural oocyte (Table 2).

In tertiary follicles the minor oocytes were larger than the minor oocytes in primary follicles. Nevertheless, some minor oocytes did not seem to grow well if they remained almost in the same position, i.e. mural, in antral follicles. Intermediate oocytes of tertiary follicles were larger than all major and minor oocytes of primary follicles; they were presumably oocytes that continued to grow and in antral follicles they would become the peripheral oocytes which are even larger.
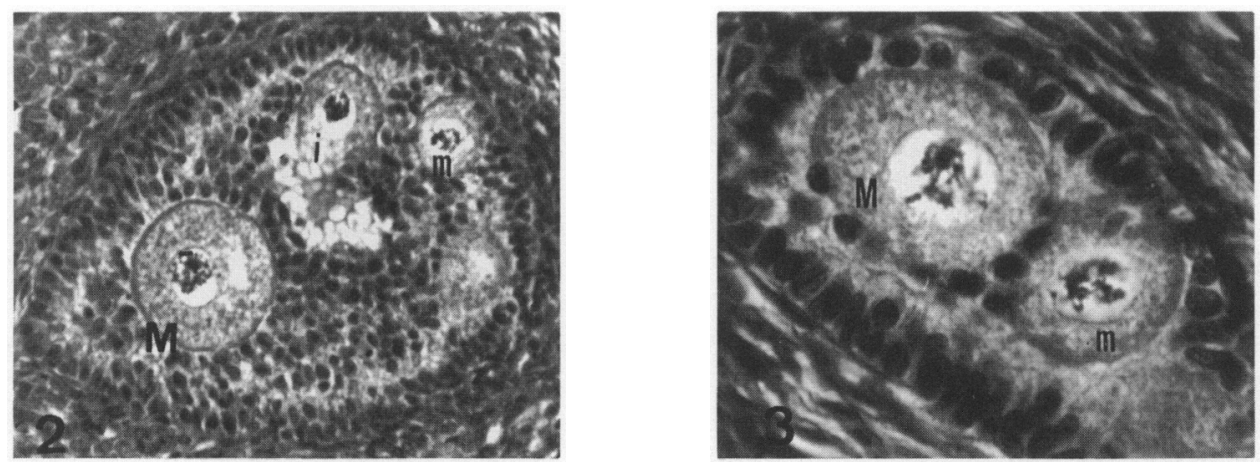

Fig. 2. A tertiary follicle with the main oocyte (M) nearer to the centre and the minor $(\mathrm{m})$ and intermediate (i) oocytes being identified according to the number of granulosa layers. $\times 200$.

Fig. 3. A primary follicle with two oocytes, a major $(\mathrm{M})$ and a minor $(\mathrm{m})$. The follicle is in the process of becoming secondary as a second row of granulosa cells is in formation. $\times 480$. 
Table 2. Comparison of oocyte size $(\mu \mathrm{m})$ according to stage of development and follicle type

\begin{tabular}{|c|c|c|c|c|c|c|c|c|}
\hline \multirow{4}{*}{$\begin{array}{l}\text { Stage of } \\
\text { follicle } \\
\text { develop- } \\
\text { ment }\end{array}$} & \multicolumn{6}{|c|}{ Polyovular follicles (POF) } & \multirow{2}{*}{\multicolumn{2}{|c|}{ Monovular follicles }} \\
\hline & \multicolumn{3}{|c|}{ With 2-3 oocytes } & \multicolumn{3}{|c|}{ With $>3$ oocytes } & & \\
\hline & \multicolumn{3}{|c|}{ Oocyte type } & \multicolumn{3}{|c|}{ Oocyte type } & $\begin{array}{l}\text { In POF } \\
\text { ovaries }\end{array}$ & Controls \\
\hline & Minor & Intermed. & Major & Minor & Intermed. & Major & & \\
\hline Primary & $36.8 \pm 1.3 \dagger$ & & $\begin{array}{l}34.4 \pm 0.6^{*} \\
51.9 \pm 1.4{ }^{\circ}\end{array}$ & & & $32 \cdot 5 \pm 1 \cdot 1$ & $48 \cdot 9 \pm 1 \cdot 5^{\mathrm{a}}$ & $42 \cdot 6 \pm 0.7^{b}$ \\
\hline \multirow{3}{*}{$\begin{array}{l}\text { Secondary } \\
\text { Tertiary }\end{array}$} & $43.9 \pm 1.9^{b}$ & & $68 \cdot 0 \pm 2 \cdot 1$ & $33 \cdot 5 \pm 0 \cdot 8^{8}$ & & $47 \cdot 3 \pm 2 \cdot 4$ & $64 \cdot 9 \pm 1 \cdot 6^{\mathrm{c}}$ & $60 \cdot 5 \pm 1 \cdot 4^{\circ}$ \\
\hline & $45 \cdot 7 \pm 2 \cdot 9^{\mathrm{a}}$ & $59 \cdot 5 \pm 2 \cdot 4$ & $74 \cdot 0 \pm 1 \cdot 7$ & $35 \cdot 4 \pm 0 \cdot 7^{8}$ & $49 \cdot 2 \pm 1 \cdot 5$ & $62 \cdot 3 \pm 2 \cdot 6$ & $80 \cdot 0 \pm 1 \cdot 2^{d}$ & $83 \cdot 0 \pm 0 \cdot 9^{d}$ \\
\hline & Mural & Peripheral & Central & Mural & Peripheral & Central & & \\
\hline \multirow{2}{*}{$\begin{array}{l}\text { Antral } \\
\text { Preovu- } \\
\text { latory }\end{array}$} & $38 \cdot 5 \pm 2 \cdot 9$ & $65 \cdot 5 \pm 2 \cdot 6$ & $84.9 \pm 1 \cdot 1^{\mathrm{e}}$ & $36 \cdot 9 \pm 1 \cdot 5^{8}$ & $56 \cdot 0 \pm 1 \cdot 5$ & $70 \cdot 9 \pm 3 \cdot 9$ & $83 \cdot 1 \pm 1 \cdot 6^{\mathrm{e}}$ & $84 \cdot 3 \pm 1 \cdot 1^{\mathrm{e}}$ \\
\hline & $55 \cdot 0 \pm 1 \cdot 2 \ddagger$ & $73 \cdot 0 \pm 2 \cdot 0_{+}^{+}$ & $78 \cdot 6 \pm 2 \cdot 0^{f}$ & 0 & 0 & 0 & $73 \cdot 4 \pm 1 \cdot 6^{f}$ & $77 \cdot 9 \pm 1 \cdot 3^{f}$ \\
\hline
\end{tabular}

Values are mean \pm s.e.m.

*Both primary oocytes equal.

†One primary oocyte is larger than the other.

$\ddagger$ Preovulatory oocyte values were too scarce to be statistically treated.

a $-\mathrm{g}$ Means with different letters are significantly different (at least $P<0 \cdot 05$ ).

In preovulatory follicles, central oocytes resumed meiosis (metaphase II, first polar body) as expected with the time of recovery of the ovaries $(8 \mathrm{~h}$ post coitum). These central oocytes were surrounded by a normally expanded cumulus. Peripheral oocytes may resume meiosis if they attain the necessary size, but the cumulus was much less expanded (Figs 4a, b, c, d; Figs 5a, b, c). Mural oocytes remained at a dictyate stage without any dissociation of the surrounding granulosa (Fig. 6).

Only 5 preovulatory follicles were observed, a small number but not surprisingly low, considering that only 106 primary polyovular follicles were observed in all ovaries. In antral and preovulatory follicles oocytes were always dispersed inside the follicle, despite their closeness in primary follicles.

Although mural oocytes in antral follicles occurred less frequently $(6 / 70)$ than minor oocytes in tertiary follicles $(28 / 107)$, peripheral oocytes in antral follicles were more numerous $(31 / 70)$ than intermediate oocytes in tertiary follicles $(22 / 107)$ (Table 1$)$. Consequently some minor oocytes must have moved to a peripheral position.

To ascertain whether there was an increase of atresia in polyovular follicles, the proportions of preovulatory to antral follicles were assessed in the 2 ovaries containing preovulatory polyovular follicles. There was no significant difference; in monovular follicles there were 29 preovulatory of 255 antral follicles, and in polyovular follicles there were 5 preovulatory of 22 antral follicles.

Follicles with 4 or more oocytes. In the 2 ovaries of one doe there were, as well as follicles with 2-3 oocytes, 24 follicles with 4-24 oocytes. In the other polyovular ovaries we observed only two follicles of this type. When more than 3 oocytes were present, oocytes of all categories were smaller than those in follicles with 2-3 oocytes (Table 2). In preantral follicles their measurement was inversely proportional to the growing number (Fig. 7) but the hierarchy of size remained the same as in follicles with $2-3$ oocytes.

Mural oocytes in antral follicles were less numerous (34/65) than minor oocytes in tertiary follicles $(58 / 82)(P<0 \cdot 05)$. These minor oocytes may grow to become peripheral ones, but to a lesser extent than in follicles with 2-3 oocytes. This stresses again the detrimental effect of a higher number of oocytes in the same follicle (Table 1).

However, most of the supernumerary oocytes in these follicles were small, either minor oocytes or primordial. Not all oocytes would achieve the size necessary to resume meiosis but in all follicles there 

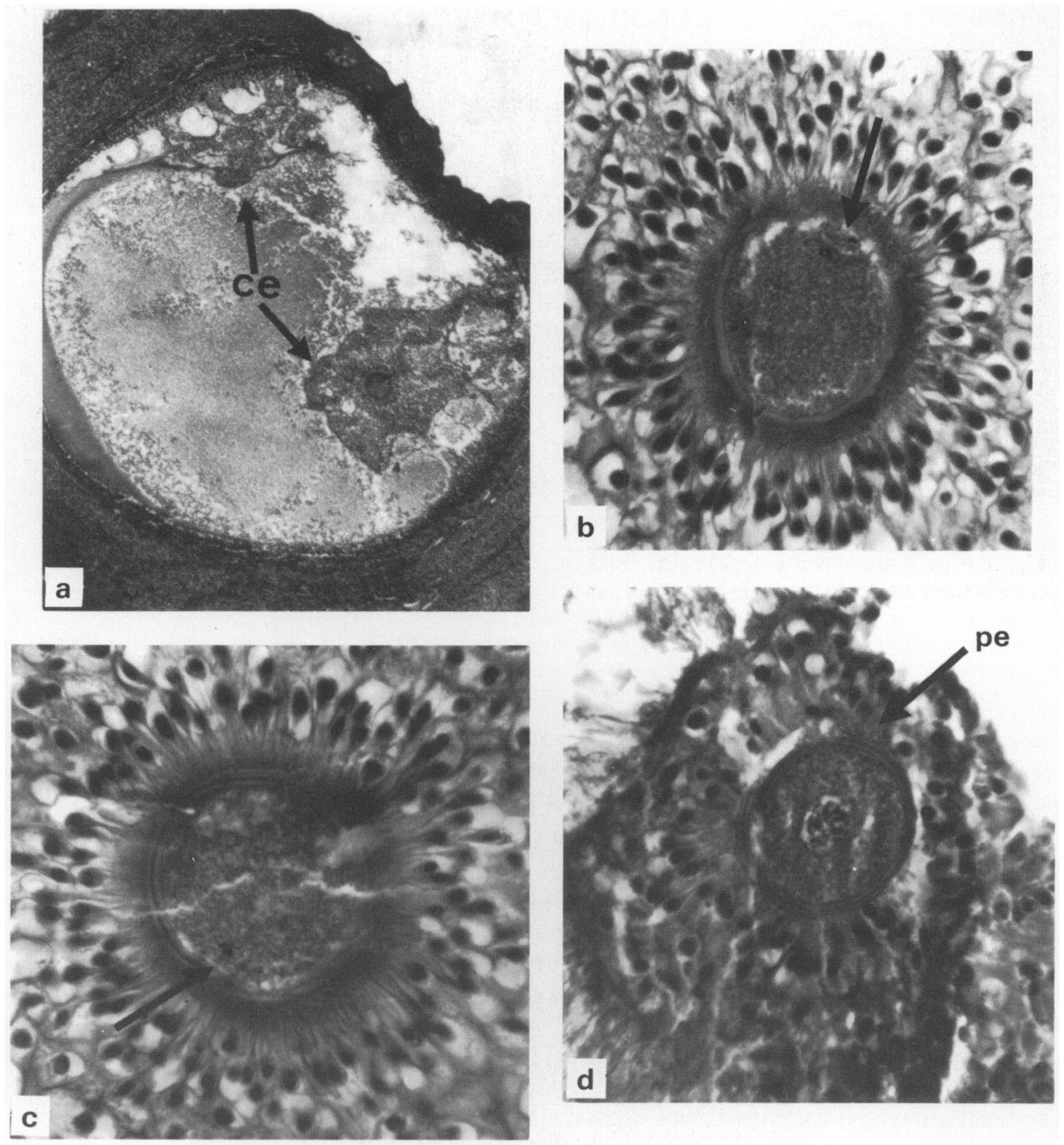

Fig. 4. A preovulatory follicle containing 3 oocytes, two major or central with a dissociated cumulus and one peripheral: (a) low-power section showing only one major oocyte, $\times 30$; (b, c) both major oocytes with the 1st polar body (arrow), metaphase Il and dissociated cumulus, $\times 300$; and $(\mathrm{d})$ the peripheral oocyte $(\mathrm{pe})$ in the dictyate stage and with intermediate cumulus, $\times 300$.

was at least one major oocyte that almost attained that size. We did not observe any preovulatory follicle with more than 3 oocytes.

Comparison of the size of oocytes in control and polyovular follicles

As shown in Fig. 8 and Table 2, the size of the oocytes in normal follicles increased progressively. Oocytes in tertiary and antral follicles were of similar size, one that is necessary for the resumption of meiosis. Oocytes were smaller in preovulatory follicles because of the loss of the first polar body. 

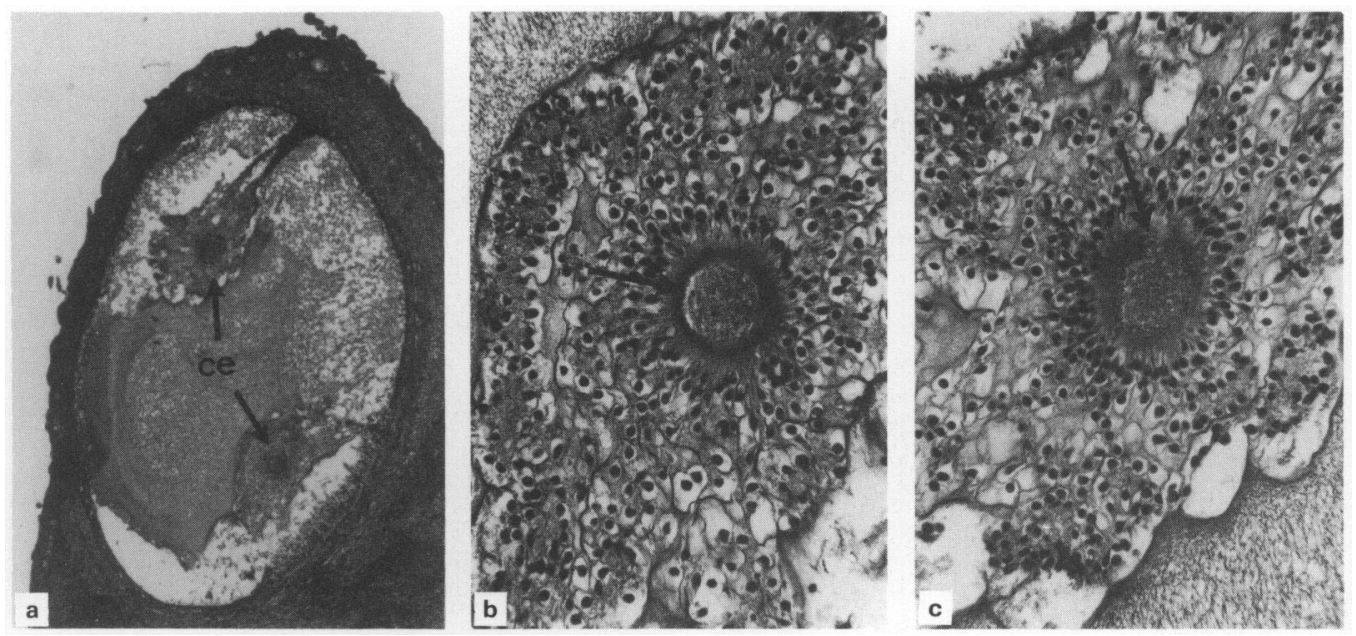

Fig. 5. A preovulatory follicle with two oocytes: both have resumed meiosis and the cumulus of each is dissociated. Arrows indicate first polar body: a, $\times 30 ; b, c, \times 300$.

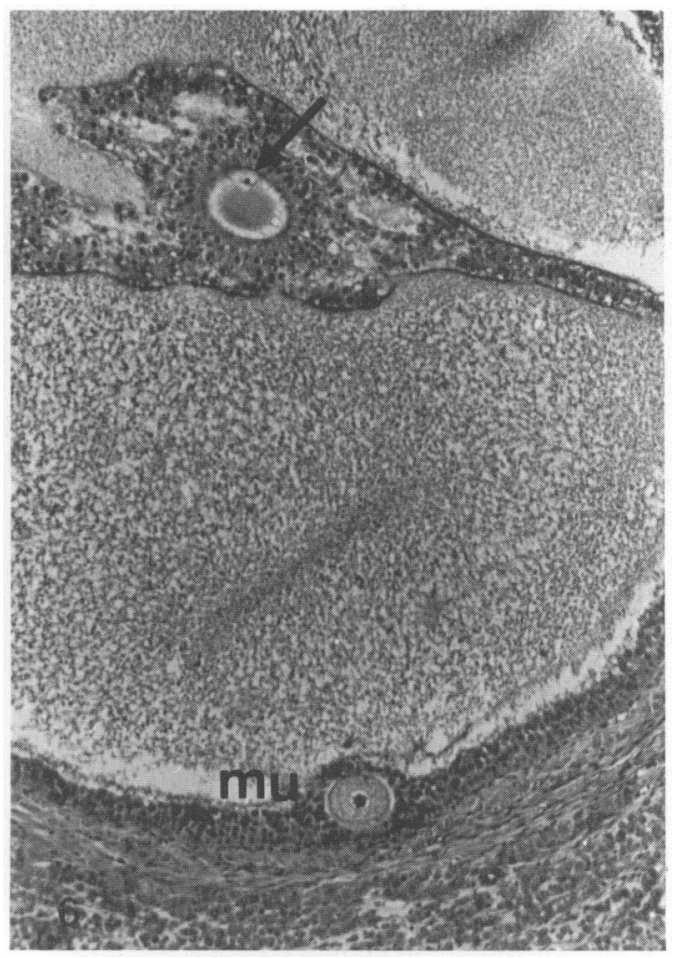

Fig. 6. A preovulatory follicle with two oocytes. The central oocyte has resumed meiosis, shows the 1st polar body (arrow) and is surrounded by a dissociated cumulus. The mural (mu) oocyte is still in the dictyate stage and there is no reaction of the surrounding granulosa cells. $\times 75$. 


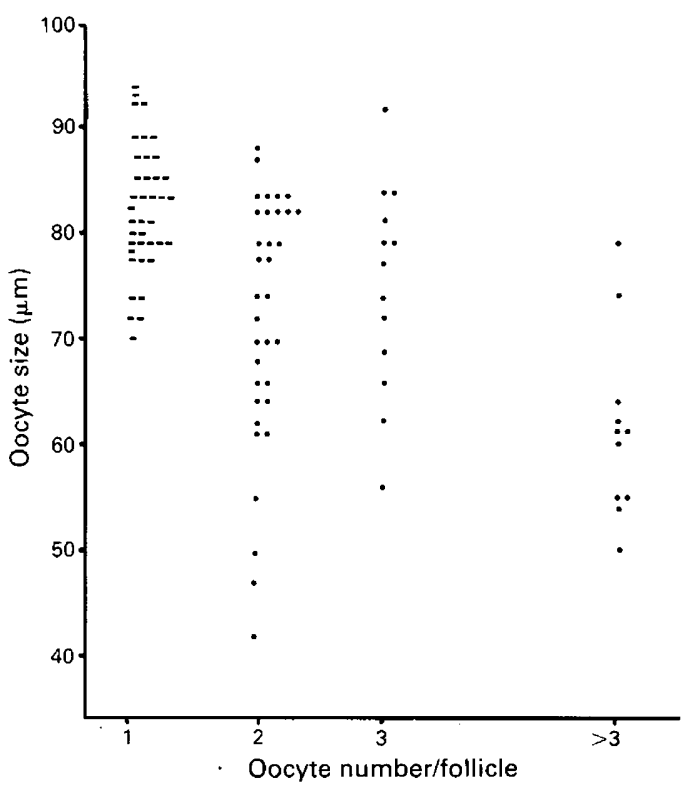

Fig. 7. Comparison of size of oocytes in polyovular follicles in relation to the number of oocytes in each follicle. Only major oocytes of tertiary follicles are represented; the 1 oocyte/follicle (1st column) values are from monovular follicles of control ovaries.

Oocytes from monovular follicles in ovaries with polyovular follicles were similar in size to those of control follicles but the dispersion of values was bigger at the primary stage $(P<0.001)$ (Table 2).

The diameters of oocytes in control follicles of both types were generally different from those of polyovular follicles (Table 2). The growth pattern was also different. In primary and secondary follicles, the main oocytes can achieve a bigger size than in controls, for instance in secondary follicles $(68.0 \pm 2.1$ vs $60.5 \pm 1.4)(P<0.01)$, probably because it takes a longer time to reach the next stage of follicular development.

However, in tertiary follicles, major oocytes were smaller than in both controls and values were more dispersed. The oocytes in control follicles of both types had reached the maximum size; major oocytes in polyovular follicles would achieve this size only later, in antral follicles, when dispersion of the values was reduced and similar to that in controls (Fig. 9).

In polyovular follicles with $\geqslant 4$ oocytes the difference between major oocytes and control oocytes was clearcut.

\section{Discussion}

We demonstrate for the first time in a mammalian species that polyovular follicles are able to accomplish the whole course of folliculogenesis from primary to preovulatory follicles. Hartman (1926), Papadaki (1978) and Szöllösi (1978) found no morphological differences between oocytes in primary monovular or polyovular follicles by light or electron microscopy. Bodemer \& Warnick (1961) thought that polyovular oocytes are only morphological and not physiological variants.

We have shown that only the more centrally located oocytes are able in due course to become preovulatory oocytes. The central position is more favourable than the more eccentric one and it is only exceptionally that two oocytes occupy this central situation. The size of the central oocyte approaches that of control oocytes, which is not the case for the eccentric ones. If the follicle yields 


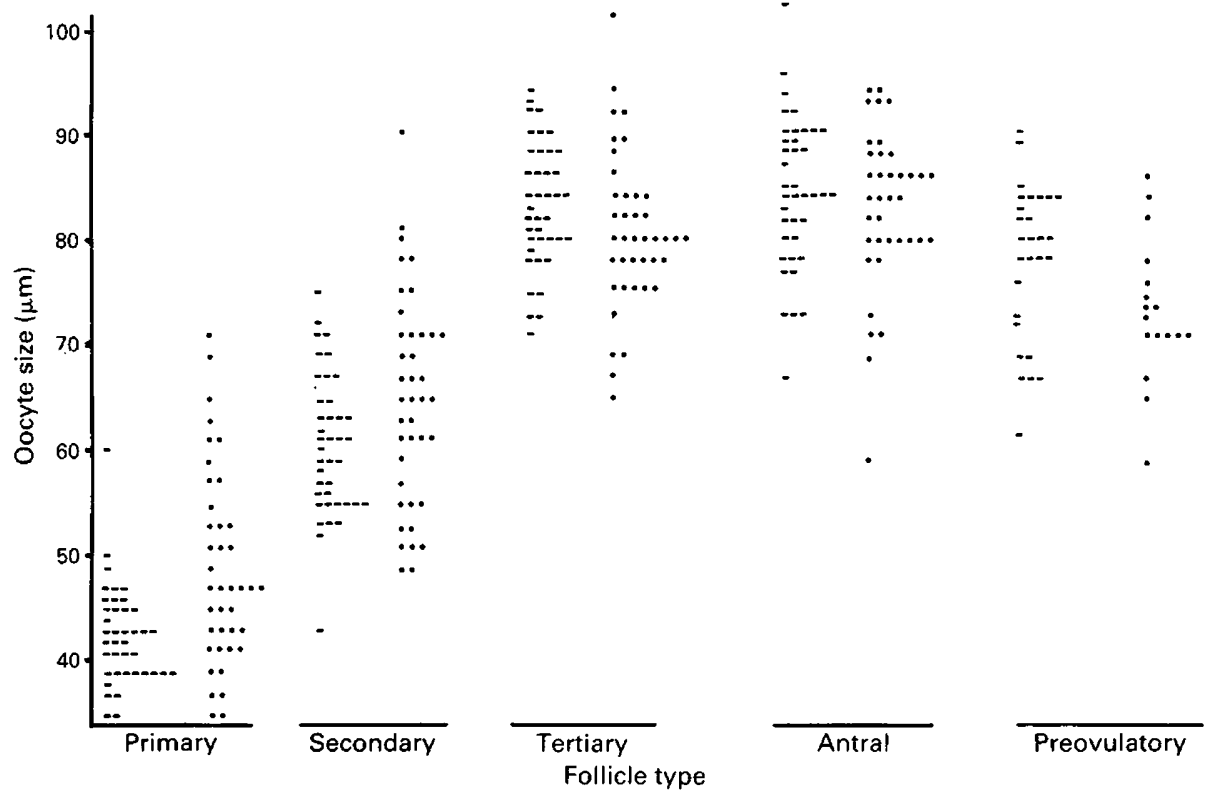

Fig. 8. Changes in the size of oocytes in monovular follicles from control ovaries ( -$)$ and ovaries also containing polyovular follicles $(\boldsymbol{O})$.

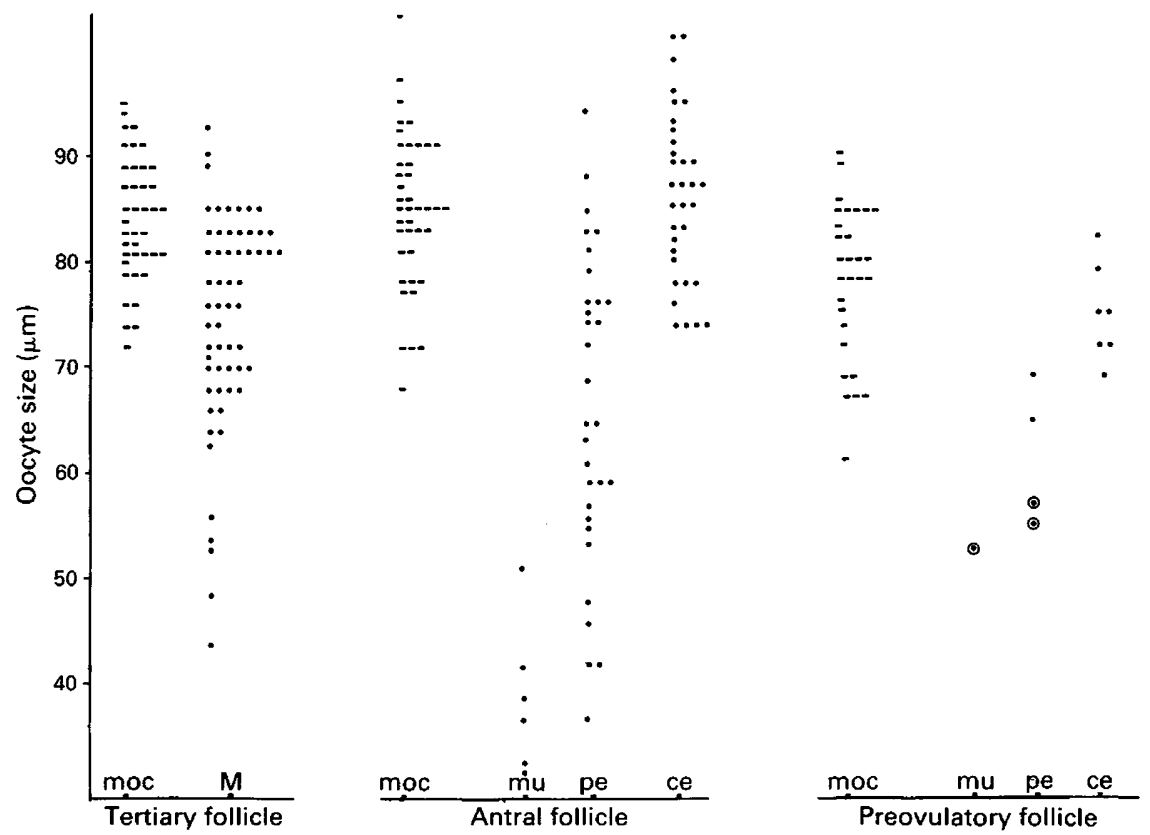

Fig. 9. Comparison of the size of oocytes in monovular control follicles $(-)$ with oocytes in polyovular follicles with $2-3$ oocytes $(\odot),(\odot)$, oocytes not having resumed meiosis like the rest of the preovulatory oocytes. moc $=$ oocytes of controls; $\mathbf{M}=$ major oocyte in tertiary follicle; $\mathrm{mu}=$ mural oocyte in antral and preovulatory polyovular follicle; $\mathrm{pe}=$ peripheral oocyte in antral and preovulatory polyovular follicle; ce = major oocyte in antral and preovulatory polyovular follicle. 
more than 3 oocytes, all of them are smaller. Two selective processes determine the topographical position and in consequence the ability of oocytes in polyovular follicles to develop.

The first selective process appears to occur in the primary follicle, where the topographical position of the two oocytes appears similar, although both are disadvantaged being in the same follicle. Once the selection has occurred, one oocyte becoming larger than the other, it grows even beyond the control size: this occurs also with the major oocyte of the secondary follicle. It indicates that polyovular follicles take longer than in controls to proceed from the primary to the secondary and then to the tertiary size.

The second selection process occurs during the progress from tertiary to antral follicles, and the major oocyte reaches the optimal size needed for the resumption of meiosis later than in control follicles. Once optimal size is reached, in the few observed preovulatory polyovular follicles, normal resumption of meiosis is accompanied by an expansion of the cumulus, both events being synchronous with those of monovular follicles. Only follicles with 2-3 oocytes yielded preovulatory follicles. The scarcity of antral follicles with $\geqslant 4$ oocytes does not allow any conclusion about their eventual ability to develop further.

These observations demonstrate that the major oocyte in a preovulatory follicle is not physiologically or morphologically different from that of a control follicle.

With reference to dizygotic twinning, our work shows (1) that polyovular follicles can develop to the preovulatory stage and (2) not all the oocytes in the preovulatory follicle are able to resume meiosis.

The presence of about $1 \%$ of preovulatory polyovulatory follicles has been deduced for human ovaries (Zeilmaker et al., 1983; Simonetti et al., 1985). However, accidental simultaneous aspiration of two preovulatory oocytes from different follicles is a possible source of error. Moreover, simultaneous retrieval of two oocytes of different types, one in metaphase II, the other in dictyate stage, a possible situation in a polyovular follicle, because of different positions of oocytes within the follicle, would be considered as indicating that the oocytes had come from two different follicles.

Only $0.4 \%$ of human primary follicles are polyovular (Gougeon, 1981). Taking into account the high percentage of follicular atresia until ovulation, the probability of a polyovular follicle ovulating is very low. Furthermore, the delay of central oocytes in reaching optimal size may affect normal post-fertilization development as chronological disturbances of the process of preovulatory development are known to have unfavourable consequences on embryo survival. Therefore, dizygotic twinning from two oocytes in the same follicle is very unlikely. The eccentric situation delays growth but does not stop it, demonstrating a continuous relation with contiguous follicular cells. This limitation of growth capacity could be explained by a substance gradient inside the follicle, the central ovum being more favoured. Only a limited amount of this substance is provided in each follicle so that the presence of more than 3 oocytes will make their growth even more limited.

We conclude that there is a relation between the topographical situation of the oocyte inside the follicle and its potential to grow. The ability to resume meiosis is probably a consequence of having attained a certain size necessary for further development. Peripheral oocytes were unable to resume meiosis at smaller size than in controls (Fig. 9). The only mural oocyte observed in a preovulatory follicle was at the dictyate stage presumably because of its size and topographical situation, although seemingly exposed to the same hormonal milieu.

The expansion of the cumulus around the preovulatory oocytes is equally puzzling. Only the central oocytes are surrounded by a normally expanding cumulus; peripheral oocytes may resume meiosis, but the cumulus expansion is only partial, and seems to depend on the topographical situation and not on a physical constraint as enough antral space is available. Mural oocytes in the same follicles are surrounded by ordinary granulosa cells. This may be related to an intrafollicular substance gradient, or be a result of oocyte maturity, suggesting that small dictyate oocytes are unable to influence the surrounding granulosa cells. A reciprocal interaction between the oocyte and the periovular cells is a possibility. 
We thank Dr R. G. Gosden (Edinburgh, U.K.) and Dr S. Ullman (Glasgow, U.K.) for helpful information and discussion; I. Durand-Gasselin for skilful technical assistance; L. Vu N. Huyen and D. Christidès for valuable co-operation in the preparation of illustrations; and J. Moret (INRA, Jouy-en-Josas) for the provision and treatment of animals.

\section{References}

Bacsich, P. (1949-1950) Multinuclear ova and multiovular follicles in the young human ovary and their endocrinological significance. J. Endocr. 6, i-ii.

Baker, T.G. (1982) Oogenesis and ovulation. In Reproduction in Mammals: 1. Germ Cells and Fertilization, 2nd edn, pp. 12-45, Eds C. R. Austin \& R. V. Short. Cambridge University Press.

Bodemer, C.W. \& Warnick, S. (1961) Polyovular follicles in the immature hamster ovary. II: The effects of gonadotropic hormones on polyovular follicles. Fert. Steril. 12, 353-364.

Davis, D.E. \& Hall, O. (1950) Polyovular and anovular follicles in the wild Norway rat. Anat. Rec. 107, $187-192$.

Dawson, A.B. (1951) Histogenetic interrelationships of oocytes and follicle cells. Anat. Rec. 110, 181-197.

Engle, E.T. (1927) Polyovular follicles and polynuclear ova in the mouse. Anat. Rec. 35, 341-343.

Gougeon, A. (1981) Frequent occurrence of multiovular and multinuclear oocytes in the adult human ovary. Fert. Steril. 35, 417-422.

Hartman, C.G. (1926) Polynuclear ova and polyovular follicles in the opossum and other mammals, with special reference to the problem of fecundity. $A m . J$. Anat. 37, 1-51.

Kent, H.A. (1962) Polyovular follicles and multinucleate ova in the ovaries of young hamster. Anat. Rec. 143, $345-349$.
Papadaki, L. (1978) Binovular follicles in the adult human ovary. Fert. Steril. 29, 342-350.

Plachot M., Mandelbaum, J. \& de Grouchy, J. (1977) Follicules multiovocytaires chez deux hamsters femelles apparentées et étude de leur méiose in-vitro. Une explication possible de la gémellité héréditaire. Annls Génét. (Paris) 20, 167-170.

Shehata, R. (1974) Polyovular Graafian follicles in a newborn kitten with a study of polyovuly in the cat. Acta anat. 89, 21-30.

Simonetti, S., Veeck, L. \& Jones, H.W. (1985) Correlation of follicular fluid volume with oocyte morphology from follicles stimulated by human menopausal gonadotropin. Fert. Steril. 44, 177-180.

Snedecor, G.W. \& Cochran, W.G. (1957) Statistical Methods, 5th edn, pp. 132-146, Iowa State University Press, Ames.

Szöllösi, D. (1978) Desmosomes: their occurrence between adjacent primary oocytes in polyovular follicles in the rabbit. Cell Tiss. Res. 191, 115-119.

Zeilmaker, G.H., Alberda, A.Th. \& Van Gent, I. (1983) Fertilization and cleavage of oocytes from a binovular human ovarian follicle: a possible cause of dizygotic twinning and chimerism. Fert. Steril. 40, 841-843.

Received 27 January 1987 